\title{
Phytochemical,Physicochemical, Anti-Nutritional And Fatty Acids Composition Of Soldier Termites (Coptotermes Gestroi) From Paikoro Local Governvernt, Niger State, Nigeria
}

\author{
*Mathew T.J., Ndamitso, M. M., Shaba E.Y., Mustapha S.,Muhammed S.S. and \\ Adamu A. \\ Department of Chemistry, Federal University of Technology, P. M. B. 65, Minna, Nigeria.
}

\begin{abstract}
Summary: The anti-nutritional contents of Coptotermes gestroi were determined using various standard methods. The results show that this insect has low cyanide (2.04 \pm 0.09$)$, phytate (25.05 \pm 1.51$)$ and oxalate content (13.46 \pm 0.64$) \mathrm{mg} / 100 \mathrm{~g}$. The phytochemical screening obtained in this work revealed the presence of alkaloids, flavonoids,cardiac glycosides, tannins, saponins, reducing sugars, sterols and terpenoids in the aqueous crude extracts whileanthraquinones was in active in three extracts. The physicochemical parameters of

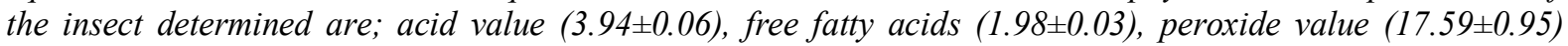
$\mathrm{mEqvO}_{2} / \mathrm{kg}$, Saponification content $(174.66 \pm 0.61) \mathrm{mg} / \mathrm{KOH} / \mathrm{g}$ and iodine value (92.62 \pm 0.33$) \mathrm{mg} / 100 \mathrm{~g}$ as well as specific gravity and refractive index, however these values fell within the nutritionally accepted values. The presence of both saturated and unsaturated fatty acids in the C. gestroi could be an advantage since both may complement the function of one another. Thus this oil is expected to be suitable for the manufacture of soaps, lubricating oil, candles thereby making them attractive options for commercial purpose and also in pharmaceutical industries.
\end{abstract}

Keywords:Phytochemical constituent, Coptotermes gestroi, Fatty acid profile, Anti-nutritional and Physicochemical properties

\section{Introduction}

Insects are the most successful prolific group of organism in the animal kingdom, constituting of about $76 \%$ of known species of surviving animal. They also played an important part in the history of human nutrition in Africa, Asia and Latin America [1].

Soldier termites, (Coptotermes gestroi)belong to the family Rhinotermitideae and are known by various names: Eka-Tiko in Nupe, Garah in Hausa, Oba-Ikan in Yoruba and Ijere in Igbo [2]. They are social insects living in colonies of different castes. Although there are slightly different species of termites, a typical termite colony has three castes all of which work to ensure the ultimate survival of the colony. Of these three castes, soldier termites, which are equipped with enlarged mandibles, are responsible for the protection of the colony [2]. It is consumed while boiled, smoked or fried and served as snacks or taken with carbohydrate foods. There is limited literature data on the nutritional composition of these popular insects among the communities. This study reports the proximate, mineral and anti-nutritional properties of this insect.

\section{Materials And Methods}

Sample collection:

The soldier termites (Coptotermes gestroi) were harvested from several anthills between the months of April and June, 2012 at Paiko village in Paikoro Local Government Area in Niger State, Nigeria. They were washed with distilled water, sun-dried for about 48 hours and finally ground into powder and stored in air-tight containers for further analyses.

\section{Methods}

Physicochemical properties

Physicochemical parameters were determined using the standard method of Official Analytical Chemists [3].

Fatty acids compositions

The fatty acid analysis was carried out using GCMS. The fatty acids were observed as peaks whose retention times were measured by the spectrometer detector and compared with those of known standards of the Wiley library.

\section{Phytochemical constituents}

Phytochemical screening was carried out according to method as described by Sofowara, [4].

Anti-nutritional properties 
Oxalate and cyanide contents were determined using the method of Day and Underwood, [5]. Phytate content was determined by the method described by Wheeler and Ferrel, [6].

Values are means $\pm \mathrm{SD}$ of three determinations

Table 1. Physicochemical parameters of the oil Extracted from Coptotermes gestroi

\begin{tabular}{ll} 
Parameters & Values \\
\hline Acid value & $3.94 \pm 0.06$ \\
Free fatty acids(as oleic) & $1.98 \pm 0.03$ \\
Iodine value $(\mathrm{mg} / 100 \mathrm{~g})$ & $92.62 \pm 0.33$ \\
Saponification value $(\mathrm{mgKOH} / \mathrm{g})$ & $174.66 \pm 0.61$ \\
Peroxide value $\left(\mathrm{m} \mathrm{Eqv} \mathrm{O}_{2} / \mathrm{kg}\right)$ & $17.59 \pm 0.95$ \\
Specific gravity & $0.78 \pm 0.03$ \\
Refractive index & $1.2067 \pm 0.06$ \\
Colour & Brown \\
\hline
\end{tabular}

Table 2. Anti-nutritional composition of Comptotermes gestroi

\begin{tabular}{lc}
\hline Parameters & Concentration $(\mathrm{mg} / 100 \mathrm{~g})$ \\
\hline Cyanide & $2.04 \pm 0.09$ \\
Phytate & $25.05 \pm 1.51$ \\
Oxalate & $8.46 \pm 1.51$ \\
\hline
\end{tabular}

Values are means \pm SD of three determinations.

Table 3. Fatty Acid Composition of the lipid Extracted from Coptotermes gestroi

\begin{tabular}{llll} 
S/N & Fatty acid & Trivial name & Composition (\%) \\
\hline 1 & Dodecane & 2.57 \\
2 & Tetradecane & 2.23 \\
3 & Hexadecane & 1.94 \\
4 & Heptadecane & 2.16 \\
5 & Tetradecanoic acid & 4.07 \\
6 & Pentadecanoic acid & 5.47 \\
7 & n-Hexadecanoic acid & 12.22 \\
8 & 9,12-Octadecadienoic acid & 5.97 \\
9 & Triacontane & & 2.72 \\
10 & $9-$ linoleic acid & 2.63 \\
11 & Heneicosane & Oleamide & 2.50 \\
12 & Tetracontane-1,40-diol & & 3.27 \\
13 & Pentatriacontane & 3.12 \\
14 & TUFA & & 8.60 \\
15 & TSFA & & 42.27 \\
16 & TUFA/TSFA & 0.20 \\
\hline
\end{tabular}

Table4 Phytochemical Costituents of Coptotermes gestroi

\begin{tabular}{|c|c|c|c|c|}
\hline \multirow[t]{2}{*}{ Class of Compounds } & & \multicolumn{3}{|c|}{ sample } \\
\hline & Colour & $\mathbf{S T}_{\mathbf{C}}$ & $\mathbf{S T}_{\mathbf{P}}$ & $\mathbf{S T}_{\mathbf{M}}$ \\
\hline Saponnins & pale brown & - & - & + \\
\hline Flavonoids & dark yellow & - & - & + \\
\hline Sterols & Green & +++ & ++ & + \\
\hline Anthraquinones & violet or red & - & - & - \\
\hline Terpenoids & pink to purple & + & ++ & +++ \\
\hline Tannins & blue, black or purple & +++ & ++ & + \\
\hline Cardiac glycosides & violet ring & + & + & + \\
\hline Alkaloids & turbidity or precipitate & +++ & +++ & ++ \\
\hline Wagners & & ++ & + & + \\
\hline
\end{tabular}


Phytochemical, Physicochemical, Anti-Nutritional And Fatty Acids Composition Of Soldier Termite

\section{Marquis}

Mayers

Molisch

Note: $\mathrm{ST}_{\mathrm{C}}=$ Coptotermes gestroi chloroform extract, $\mathrm{ST}_{\mathrm{P}}=$ Coptotermes gestroi petroleum extract, $\mathrm{ST}_{\mathrm{M}}=$ Coptotermes gestroimethanol extract, $+++=$ Strongly active, $++=$ Moderately active, $+=$ Weakly active and - = Inactive.

Saponification value is used in checking adulteration. The high saponification value of the sample (174.66 $\pm 0.61 \mathrm{mgKOH} / \mathrm{g}$ for $C$. gestroi) suggested that the oil could be quite suitable for cosmetic production [7]. This value was lower than the $189.22 \pm 0.92 \mathrm{mgKOH} / \mathrm{g}$ and $198.26 \pm 0.99 \mathrm{mgKOH} / \mathrm{g}$ reported for the skin and DFC from R. palmarum L. larva oils by Edmond et al. [8]. The low iodine values of the oils indicated that they have low contents of unsaturated fatty acids. This showed that these oils will not be more susceptible to oxidation deterioration thus they will be easily stored for a long time without spoilage [9]. Thus these oils are expected to be suitable for the manufacture of soaps, lubricating oil, candles thus making them attractive options for commercial purpose thus minimizing the dependence on use of know edible oils for making such products [10]. The iodine value of $C$. gestroi oil was $92.62 \pm 0.33 \mathrm{gI}_{2} / 100 \mathrm{~g}$. This was lower than the $108.00 \pm 0.15$ reported for M. bellicosusoil by Ekpo and Onigbinde [11]. This value was however, higher than the $48.35 \pm 0.55 \mathrm{gI}_{2} / 100 \mathrm{~g}$ reported for $R$. palmarum L. larva by Edmond et al. [8]. This implied that, the oils obtained from this work could be used in the production of lubricating oils, candles and soaps which will reduce the dependence on the known edible oils for making such products. The acid value of an oil is a direct measure of the percentage content of free fatty acids in a given amount of the oil. This value depends on the degree of rancidity which is used as an index of freshness [10]. The acid value of $C$. gestroi oil was $3.94 \pm 0.06 \mathrm{mgKOH} / \mathrm{g}$. This value was higher than the $2.21 \pm 0.02 \mathrm{mgKOH} / \mathrm{g}$ reported for DFC but similar to the $4.72 \pm 0.06 \mathrm{mgKOH} / \mathrm{g}$ reported for the skin of $R$. palmarum L. larva by Edmond et al. [8]. The low acid value obtained in this study gave an indication of its lower susceptibility to rancidity which depicted a higher shelf life. The peroxide value of oil is a sign of its rancidity, thus a high peroxide value of oil indicates a poor resistance of the oil to peroxidation during storage [12]. The Peroxide value of $17.59 \pm 0.95 \mathrm{mEqO}_{2} / \mathrm{kg}$ was recorded for $C$. gestroi. The peroxide value obtained in this work was lower than the $20.00 \pm 080 \mathrm{meqO}_{2} / \mathrm{mg}$ reported for M. bellicosus by Agomuo [13]. The peroxide value obtained from this work indicated that, this oil will take long time before they deteriorate. The refractive index indicates the level of optical clarity of the oil sample relative to water. The refractive index of $1.2067 \pm 0.06$ was recorded for $C$. gestroi. Similar values of the 1.4672 reported for $C$. albidunm by Adebayo et al. [14]. This implies that the oil obtained from this insect are lighter and could be considered to be of high quality and as such find much use in the pharmaceutical industries. The specific gravity of $0.79 \pm 0.03$ was obtained for C. gestroi. Similar value was obtained for C. albidun (0.89)by Adebayo et al. [14]. Free fatty acids are more susceptible to lipid oxidation, leading to rancidity and production of off-odour compared to intact fatty acids in the triglycerides [15]. The free fatty acid value of $C$. gestroi was $1.98 \pm 0.03 \mathrm{mgKOH} / \mathrm{g}$ and a similar value of $2.25 \mathrm{mg} / \mathrm{KOH} / \mathrm{g}$ was reported for C. albidum by Adebayo et al. [14].

The result of the level of anti-nutritional content of the insect was as presented in Table 2. Phytic acid has been implicated in the removal of phosphorus, indigestion and flatulence in human system [16]. The Phytate content of $25.05 \pm 1.51 \mathrm{mg} / 100 \mathrm{~g}$ was recorded for C. gestroi. This value was lower than the $178 \mathrm{mg} / 100 \mathrm{~g}$ reported for larva of $O$. monocerosbylfie and Emeruwa[17]. However, this value was higher than the $0.311 \mathrm{mg} / 100 \mathrm{~g}$ reported for $H$. meles and $0.276 \mathrm{mg} / 100 \mathrm{~g}$ reported for R. phoenicis by Adesina[18]. Based on the phytate value obtained from this work this insect could be consumed without much fear of harm to humans and his animals in respect of phytic acid toxicity. Oxalate is known to isolate and cause some useful metallic elements, to be deposited in solid forms, thus making them unavailable for adsorption in human system [19]. The lethal dose of oxalates is between 200 and $500 \mathrm{mg} / 100 \mathrm{~g}$ [20]. The value of oxalate content of $13.46 \pm 0.64 \mathrm{mg} / 100 \mathrm{~g}$ was recorded for C. gestroi. This value was lower than the $29.00 \mathrm{mg} / 100 \mathrm{~g}$ reported for yam beetle and $19.32 \mathrm{mg} / 100 \mathrm{~g}$ reported for palm weevil by Adesina [18]. The oxalate content obtained from this work suggested that, it could be safe for consumption as far as it oxalates content was concerned since it fell below the lethal dose limit. High level of cyanide in foods has been implicated with cerebral damage and lethargy in man and his animals [21] although most levels of this substance are generally regarded to be highly toxic to animals. NRC, [22] gave the toxic level to be between the range of 50 to $200 \mathrm{mg} / 100 \mathrm{~g}$. The cyanide content of $C$. gestroi was $2.04 \pm 0.09 \mathrm{mg} / 100 \mathrm{~g}$. This value was lower than the $2.65 \mathrm{mg} / 100 \mathrm{~g}$ reported for $H$. melesand $2.53 \mathrm{mg} / 100 \mathrm{~g}$ reported for $R$. phoenicis by Adesina [18]. The cyanide content obtained in this work showed that it consumption could be safe as far as its cyanide content was concerned.

Tables 3 show the fatty acid compositions of the lipid obtained from C. gestroi. The abundances of unsaturated fatty acids in the oils were desirable from the nutritional and health view points as unsaturated fatty acids consumption will not lead to heart related diseases while the consumption of foods rich in saturated fatty acids is implicated with certain cardiovascular disorders like atherosclerosis, cancer and aging [23][24]. The major unsaturated fatty acid in C. gestroi was linoleic and oleamide, while the trivial names of the major 
saturated fatty acids were not identified. The unsaturated fatty acids accounted for $8.60 \%$ while the saturated acids accounted for $42.27 \%$ of total fatty acids. The presence of both saturated and unsaturated fatty acids in this insect could be an advantage since they may complement the functions of one another. The ratio of the total unsaturated fatty acids to the total saturated fatty acids (TUFA/TSFA) of C. gestroi was $0.20 \%$. Thus since the recommended ratio for a healthy diet is $0.45 \%$, this oil may not be of better nutritional advantage as suggested by the UK Department of Health. Therefore this oil is not expected to have the potential of being used in the dietetic management of certain coronary heart diseases. Thus, the oil from this insect may be important in industry especially in the production of paints, emulsions, plastics, drying agents, lubricants and as additives in pharmaceutical as well as drug productions.

Table 4 shows the phytochemical constituents of $C$. gestroi. Saponins bind cholesterol, block its uptake by the intestines thus facilitating its excretion as well as the coagulation of the red blood cells [25]. These chemicals were found in the methamolic extract of this insect but not in the chloroform and petroleum ether extracts and this disparity may be due to the polarities of the solvents. Thus the presence of saponins in this insect could be explore for its possible application in medicine for the stoppage of bleeding, treat wounds and reduce the risk of heart diseases [26]. Tannins used in the treatment of intestinal disorders such as diarrhoea, dysentery and urinary tract infections [27]. Tannins were present in the three solvents employed in this study. However, methanolic extracthad high amount of tannins while chloroform extract had the lowest. The tannin content of this insect could be used to exhibit antiviral, antibacterial and antitumor activities as well as diuretics [28]. While none of the crude extracts in this study had anthraquinones, only the methananolic extract contained flavonoids. In general, flavonoids have antioxidant potentials that enhance the body defence against pathogen induced free radical generation [29]. The absence of flavonoids in both the chloroform and petroleum ether extracts in this work might be due to the disparity in polarities of the solvents. Flavonoid constituent obtained from this insect could protect blood vessels especially the tiny catapillaries that carry oxygen and nutrients to cells and are believed to slow down the development of cataracts in persons who have diabetes [30]. Steroidal compounds are of importance and interest in pharmacy due to their relationship with such compounds as sex hormones [31]. It was present in the methanol, chloroform and petroleum ether crude extracts of the insect. Thus this insect is expected to be good sources of materials that could aid the sexual prowess of humans and other animals. Cardiac glycosides have been shown to aid in the treatment of congestive heart failure and cardiac arrhythmia. All the crude extracts of the insect in this study contained cardiac glycosides. Terpenoids improve lung function [32]. These compounds were present in the petroleum ether, chloroform and methanol crude extracts of this insect. Alkaloids are used as basic therapeutic agents because of their analgesic, antispasmodic and bactericidal effects [26]. It also exhibits marked physiological activity when administered to animals. The Wagner's, Marqui's and Mayer's tests for alkaloids were positive for the crude extractsbut were negative for Molisch's test.

\section{Conclusion}

The results of anti-nutrition properties obtained from this study show that $C$. gestroi has no any effects pose to man and his animal. This result alsosuggest that the oil obtained from this insect could be exploited in industry especially in the production of paints, emulsions, plastics, soap making, drying agents, lubricants and as additives in pharmaceutical as well as drug productions. The presence of secondary metabolites in the sample indicates that this insect could be useful in the treatment of diseases cause by some microorganisms.

\section{Reference}

[1]. V.L. Yoloye, Basic Invertebrate Zoology. 1st edn.University of Ilorin Press, Ilorin, 2010, 192

[2]. L.G. KirtonandV.K. Brown, The taxonomic status of pest species of Coptotermes in Southeast Asia: Resolving the paradox inthe pest status of the termites, Coptotermes gestroi, C. havilandiandC. travians(Isoptera: Rhinotermitidae) Sociobiology.42, 2003, 4364.

[3]. Methods of the Association of Official Chemists. Official Methods of Analysis, 15th ed., Virginia Association.Official Analytical Chemists, USA, 1990, 1141

[4]. A.E. Sofowara, Medicinal plants and traditional medicine in Africa. Vol. 2. Spectrum Books Ltd, Ibadan, $1993,288$.

[5]. R.A, Day and A.L,Underwood, Qualitative Analysis. 5th Ed. New Delhi, India: Prentice Hall Publications. $701,1986$.

[6]. E.I.Wheeler and R.E.Ferrel, Methods for phytic acid determination in wheat and wheat fractions. Jour. Cereal Chem. 48,1971, 312320.

[7]. D. C.Eaton, Laboratory investigation in organic chemistry. Industry Products 5,1989, 11-14

[8]. A. D. Edmond, B. L. Z. Hervé César, E.N. K. Jean Parfait and P.K. Lucien, Fatty acid composition and properties of skin and digestive fat content oils from RhynchophoruspalmarumL. larva. African Journal of Biochemistry Research.3 (4), $2009,089-094$.

[9]. O.S. Falade, S.A. Adekunle, M.A. Aderogba, S.A. Atanda, C. Harwood and S.R.A. Adewusi, Physicochemical properties, total phenolandtocopherol of some Acacia seed oils. Journ. Sci.food Agric. 88, 2008, 263-268.

[10]. S.S. Ochigbo and Y.B. Paiko, Effects of Solvent Blending on the Characteristic of Oils Extracted from the seeds of Chrysophyllumalbidium. International Journal of science and Nature. IJSN, 2(2), 2011, 352-358.

[11]. K. E. Ekpo and A. O. Onigbinde, Nutritional potentials of Orycetes rhinoceros larva. Nigerian Journals of NutriSci 26, $2007,54-59$.

[12]. M. I. Mohammed and Z.U. Hamza, Physicochemical Properties of Oil Extracts from SesamumIndicum L. Seeds Grown in Jigawa State-Nigeria. Journal of Applied Science andEnvironment Management. 12(2), 2008, 99-101. 
[13]. E.N. Agomuo, Proximate and Fatty acid compositions of termites (Macrotermesbellicosus).International Science Research Journal. 4(2), 2011, 93-96

[14]. S.E. Adebayo, B.A. Orhevba, P.A. Adeoye, J.J. Musa and O.J. Fase, Solvent Extractionand Characteristic of oil from African Star Apple (CHRYSOPHYLLUM ALBIDUM) SEEDS. Academic Research International.3(2), 2012, 178-183

[15]. FAO, WHO, Fats and Oils in human nutrition. Report of a joint expert consultation organised by the Food and Agriculture Organization of the United Nations and the world Health Organization Rome, 19-26 October. 10, 1993, 19-26.

[16]. V.O. Ndubuakaku, A.C. Uwangbute and D.O. Nnanyelugo, Flatulence and otherAbdominal Discomforts associated with Cowpea. Appitite.13, 1988, 171- 181 .

[17]. I. Ifie and C.H.Emeruwa, Nutritional and anti-nutritional characteristics of the larvaOfOryctesmonoceros. Agriculture and Biology Journal of North America.2(1), 2011, 42- 46.

[18]. A. J. Adesina, Proximate and anti-nutritional composition of two common edibleinsects: yam beetle (Heteroligusmeles) and palm weevil (Rhynchophorusphoenicis). ElixirFood Science 49, 2012, 9782-9786.

[19]. O. T. Alamu, A. O. Amao, C. I.Nwokedi, O. A. Oke, and I. O. Lawa,Diversityand nutritional status of edible insects in Nigeria: $A$ review International Journal of Biodiversity and Conservation.5(4), 2013, 215-222.

[20]. D. Pearson, Laboratory Techniques in Food Analysis. Butter-worths, London, 1973, 33-52.

[21]. B.N. Akyildiz, S. Kurtoglu, M. Kondolot, and A. Tunc, Cyanide Poisoning causedby Ingestion of Apricot seeds. Ann.Trop. Paediatr. 30(1), 2010, 39- 43.

[22]. National Research Council, Recommended daily dietary allowance. Nutr. Rev 31,1974, $373-395$.

[23]. M. Law, Dietary fat and adult diseases and the implications for childhood nutrition: An Epidemiologic approach. American.Journal Clinic Nutr.72, 2000, 1291s-1296s.

[24]. B.S. Anita, E.J. Akpan, P.A. Okon, and I.U. Umoren, Nutritive and Anti-nutritive Evaluation of Sweet Potatoes Leaf. Pak. Journal Nutri5, 2006, 166-168.

[25]. D.E. Okwu and C. Josiah, Evaluation of the chemical composition of two Nigerian medicinal plants. African Journal Biotechnol.,5, 2006, 357-361.

[26]. R. Harisaranraj, K. Suresh and S. Saravanababu, Evaluation of the chemical composition Rauwolfiaserpentinaand Ephedra vulgaris. Adv. Biol. Res., 3, 2009, 174-178.

[27]. D.A. Akinpeluand T.MOnakoya, Antimicrobial activities of medicinal plants used in folklore remedies in south-western. African Journal Biotechnol.,5, 2006, 1078-1081.

[28]. O.O. Aiyelaagbe and P.M. Osamudiamen, Phytochemical screening for active compounds in Mangiferaindicaleaves from Ibadan, Oyo State. Plant Sci. Res., 2, 2009, 11-13.

[29]. A.I Al-Humaid, H.M. Mousa, R.A. El-Mergawi, and A.M. Abdel-Salam, Chemical composition an antioxidant activity of dates and datescamel-milk mixtures as a protective meal against lipid peroxidation in rats. Am. Journal Food Technol. 5, 2010, 22-30.

[30]. N. Sarah, N.J. Miller, G. Pagangeg, L. Tijburg, P. Bolwellg, E. Rice and C. Evans, Polyphenolic flavonoids as scavenger of aqueous phase radicals as chain breaking antioxidant. Arch. Biochem. Biophys.,2, 1995, 339-346.

[31]. D.E. Okwu, Evaluation of the chemical composition of indigenous spices and flavouring agents. Global Journal Pure Applied Sci., 7, 2001, 455-459.

[32]. E.B. Hawkins, and S.D. Ehrlich, Gotu Kola. University of Maryland Medical Center.Baltimore. USA, 2006. 